\title{
Degenerative meniskrupturer bør ikke opereres
}

De som følger med i dagspressen, har fått med seg at degenerative meniskrupturer ikke skal opereres. I hvert fall ikke med én gang. Tidligere var det en stående vits blant ortopeder at indikasjonen for kneartroskopi var oppmøte. Dette er selvfølgelig overdrevet, men meniskruptur var i de fleste tilfeller ansett som god indikasjon for artroskopi. Slik er det ikke lenger. Vi har for det meste sluttet å operere degenerative meniskrupturer - men det skjedde ikke før noen sa ganske tydelig ifra. Først fant finske kolleger at det var like god effekt av placebokirurgi som meniskreseksjon (1). Studien ble kritisert fordi den viste at det tross alt hjelper å stikke et kamera inn i kneet.

Nå finnes det imidlertid en håndfull gode randomiserte studier som viser at degenerative meniskrupturer i første omgang bør behandles konservativt. To metaanalyser av randomiserte, kontrollerte studier konkluderer med at artroskopi ved degenerative meniskrupturer hos middelaldrende har ubetydelig eller ingen effekt utover trening, og man anbefaler konservativ behandling $(2,3)$. Dette ble senere bekreftet $\mathrm{i}$ en norsk studie med 140 pasienter med degenerativ meniskruptur diagnostisert ved MR-undersøkelse (4). Pasientene ble randomisert til artroskopisk meniskreseksjon eller opptrening. Etter to år var det ingen forskjell mellom gruppene målt med kliniske og pasientrapporterte spørreskjemaer.

Etter innføringen av innsatsstyrt finansiering i offentlige sykehus og fremveksten av private institutter økte antallet kneartroskopier etter tusenårsskiftet. Økningen må ses i lys av økningen i antall MR-undersøkelser av knær. Allerede i 2006 advarte norske forskere mot dette (5). Den største økningen gjaldt pasienter over 50 år, der MR-funn sjelden har klinisk relevans. Med invasjonen av MR-undersøkelser av degenerative knær har vi erfart at det er kommet en rekke nye MRdiagnoser, som benmargsødem, kondropati og «bonebruise». I tillegg beskrives væskeansamlinger, bursaer, plikaer og kanskje en cyste. For en pasient kan det være skremmende å få en helsides beskrivelse av kneet sitt, iblandet normalfunn, bifunn og patologiske funn, selv om alt ofte kan oppsummeres som varierende grader av artrose. Vi mottar sjelden henvisninger om middelaldrende pasienter med kneplager uten et vedlagt MR-svar. Vanlig røntgenundersøkelse, derimot, er ofte ikke utført. Det synes å herske en forestilling både blant pasienter og noen leger om at en MR-undersøkelse er bedre enn en røntgenundersøkelse, men den er faktisk lite egnet til å vurdere grad av artrose. Meniskdegenerasjon med eller uten ruptur i et middelaldrende kne anses som et tidlig tegn på kneartrose. Over $35 \%$ av friske mennesker over 50 år har degenerativ ruptur av menisken på MR-undersøkelse som et tilfeldig funn (6).

Vi mottar årlig hundrevis av henvisninger med spørsmål om kirurgi hos pasienter med degenerative meniskrupturer. De fleste er unødvendige. Behandlingen er i første omgang konservativ. Rehabiliteringen kan skje i primærhelsetjenesten, med fysioterapiveiledet treningsterapi som førstevalg. Kirurgi bør bare vurderes ved manglende effekt av adekvat konservativ behandling eller der det er åpenbare mekaniske symptomer som låsninger og opphakninger. Norske ortopeder har tatt til seg denne nye kunnskapen. I 2015 ble det utført omkring 10000 meniskoperasjoner i offentlige sykehus, mot 19000 i toppåret 2009 (7). Det totale antall artroskopier er likevel vanskelig å anslå på grunn av et ganske stort privat marked finansiert via ulike helseforsikringer. Det er stor geografisk variasjon, og det er åpenbart at operativ behandling av meniskdegenerasjon i stor grad er styrt av tilbud og etterspørsel. For eksempel ble det i perioden 2011-13 utført dobbelt så mange artroskopier per innbygger i Møre og Romsdal som landsgjennomsnittet (8). Over halvparten av disse operasjonene var gjort privat.

Det er fint at det ortopediske miljøet selv nå rydder opp i misforståtte indikasjoner, slik at vi kan finne de pasientene som faktisk har nytte av de inngrepene vi utfører. Det kan være grunn til å minne om det gamle munnhellet om at det tar fem år å lære å operere, men 20 år å lære når man $i k k e$ skal operere. Vi håper og tror det går raskere for norske allmennleger å lære at pasienter med degenerativ meniskruptur primært ikke skal henvises til ortoped for operasjon, men i stedet til fysioterapiveiledet treningsterapi.

\section{Per-Henrik Randsborg \\ pran@ahus.no}

Jan Harald Røtterud

Per-Henrik Randsborg (f. 1973) er ph.d., spesialist i ortopedisk kirurgi og overlege ved Ortopedisk klinikk, Akershus universitetssykehus. Han er leder for The Norwegian Cartilage Project.

Forfatter har fylt ut ICMJE-skjemaet og oppgir ingen interessekonflikter.

Jan Harald Røtterud (f. 1971) er ph.d., spesialist i ortopedisk kirurgi og fagansvarlig overlege for kne- og skulderkirurgi ved Ortopedisk klinikk, Akershus universitetssykehus.

Forfatter har fylt ut ICMJE-skjemaet og oppgir ingen interessekonflikter.

\section{Litteratur}

1. Sihvonen R, Paavola M, Malmivaara A et al. Arthroscopic partial meniscectomy versus sham surgery for a degenerative meniscal tear. N Engl J Med 2013; 369 : 2515-24.

2. Khan M, Evaniew N, Bedi A et al. Arthroscopic surgery for degenerative tears of the meniscus: a systematic review and meta-analysis. CMAJ 2014; 186: 1057-64.

3. Thorlund JB, Juhl CB, Roos EM et al. Arthroscopic surgery for degenerative knee: systematic review and meta-analysis of benefits and harms. BMJ 2015; 350: h2747.

4. Kise NJ, Risberg MA, Stensrud S et al. Exercise therapy versus arthroscopic partial meniscectomy for degenerative meniscal tear in middle aged patients: randomised controlled trial with two year follow-up. BMJ 2016: 354: i3740.

5. Espeland A, Natvig NL, Løge I et al. Magnetic resonance imaging of the knee in Norway 2002-2004 (national survey): rapid increase, older patients, large geographic differences. BMC Health Serv Res 2007; 7: 115.

6. Englund M, Guermazi A, Gale D et al. Incidental meniscal findings on knee MR in middle-aged and elderly persons. N Engl J Med 2008; 359: 1108-15.

7. Olsson SV. Mange tusen menisk-opereres unødig. NRK 21.7.2016. https://www.nrk.no/norge/forskning_-mange-tusen-menisk-opereres unodig-1.13027827 (24.11.2016)

8. Dagkirurgiatlas. http://www.helseatlas.no/dagkirurgiatlas/atlas.html (24.11.2016). 